\title{
Empty spaces that are full of cultural history: an innovative proposal for the man- agement of a protected area of Chimborazo volcano (Ecuador)
}

\author{
Alden Mauro Yepez Noboa \\ Keywords: Chimborazo volcano, archaeological sites, cultural landscape
}

\begin{abstract}
This study positions itself in the current sociopolitical landscape of the Quichuaspeaking communities in Chimborazo Province, in the central highlands of Ecuador. These communities are striving to revitalize their local identities as peasant communities living near Chimborazo volcano. The article presents a proposal for assessing the heritage value of at least three archaeological sites identified by the author using prospection and excavation techniques between 2012 and 2016. It also seeks to further the dissemination of the results of archaeological work at the sites, both among the indigenous people living nearby and among local government entities, the Catholic church and tourism operators (from now on referred to as stakeholders). The study aims to identify the most efficient, socially inclusive, long-term sustainable mechanisms to guarantee the protection, care and management of the cultural heritage of the archaeological sites discovered near Chimborazo volcano. It also proposes that the category cultural landscape should be applied to Chimborazo volcano in order to create a new framework for natural and cultural resources administration.
\end{abstract}

\section{Profile}

Protected area

Chimborazo Fauna

Production Reserve

Mountain range

Andes Mountains,

Ecuador

\section{At the top of the vertical model, a new space to govern}

The geography of the Andean mountains of Ecuador is characterized by the short distances between the ecosystems found along the vertical gradient, this gradient following the two main cordilleras (western and eastern) of the tropical Andes. The mountains of Ecuador are all Andes de Páramo and are known as the Equatorial Andes (Sarmiento 2000). Lauer (1975) underlines the importance of water resources and temperature in the distribution of the major vegetation formations found throughout the Equatorial Andes: the tierras calientes are the huge tropical lowland rainforests in both cordilleras; the tierras templadas are the montane rain forests; the tierras frias are the tropical mountain and cloud forests; and the tierras heladas are the páramo (grasslands between 3200 and $4000 \mathrm{~m}$ a.s.l.). Settlements within the tierras heladas are located at around $3500 \mathrm{~m}$. This is important information, because all protected páramo areas in Ecuador were created with the idea that the land did not have any human settlements: the areas were no man's land (Bustamante 2013).

In the Ecuadorian Andes, the vertical gradient brings the ecosystems particularly close to one another. The ethnohistorian Oberem developed an economic model (Oberem 1978) to describe the particular character of the Ecuadorian mountains, where local people take advantage of the close proximity to each other of various ecosystems, such that they can travel to them in the course of a single day and return home at night (Oberem 1981). The páramos represent the up- per limit of areas for human activities, and are used for animal pasture or firewood collection. Above $4000 \mathrm{~m}$, permanent settlement is difficult and cannot be integrated into the traditional Andean way of life, except for religious sacrificial activities (Cerutti 2017).

In a relatively recent vertical model, Stadel (1990: 49) describes how the land at high altitudes (3000$4000 \mathrm{~m}$ ) is used for cultivation of barley and tubers, with an extension to $4000-4500 \mathrm{~m}$ for pastoralism in the humid Andes (including the Ecuadorian mountains). Like others scholars, he sets the limit of human habitation at around $4000 \mathrm{~m}$ because of hypoxia stress and respiratory problems that occur for humans at altitudes of 3000 to $6000 \mathrm{~m}$. At around $4500 \mathrm{~m}$, the snow line coincides with the absence of human settlements (Stadel 1990: 49, 50).

It is interesting to note the logic for the creation of protected areas (PAs) and natural parks in Ecuador at the páramo altitude: if no visible, human activities were taking place in an area, and there was no clear evidence of settlements, the area was assumed to be uninhabited and, therefore, should be protected. The lands were simply taken over by the state; PAs created in this manner cover thousands of hectares.

In 1987, the Reserva de Producción Faunistica de Chimborazo (RPFCH; Chimborazo Fauna Production Reserve) was created in the central region of the Ecuadorian mountains (Acuerdo 437, Registro Oficial 806, Nov. 9, 1987). Previously created PAs were conceived as nature conservation areas, or were for human recreation purposes through tourism. The $\mathrm{RPFCH}$ was the first PA in Ecuador to embody the idea of giving specific animal species a natural space for their sur- 


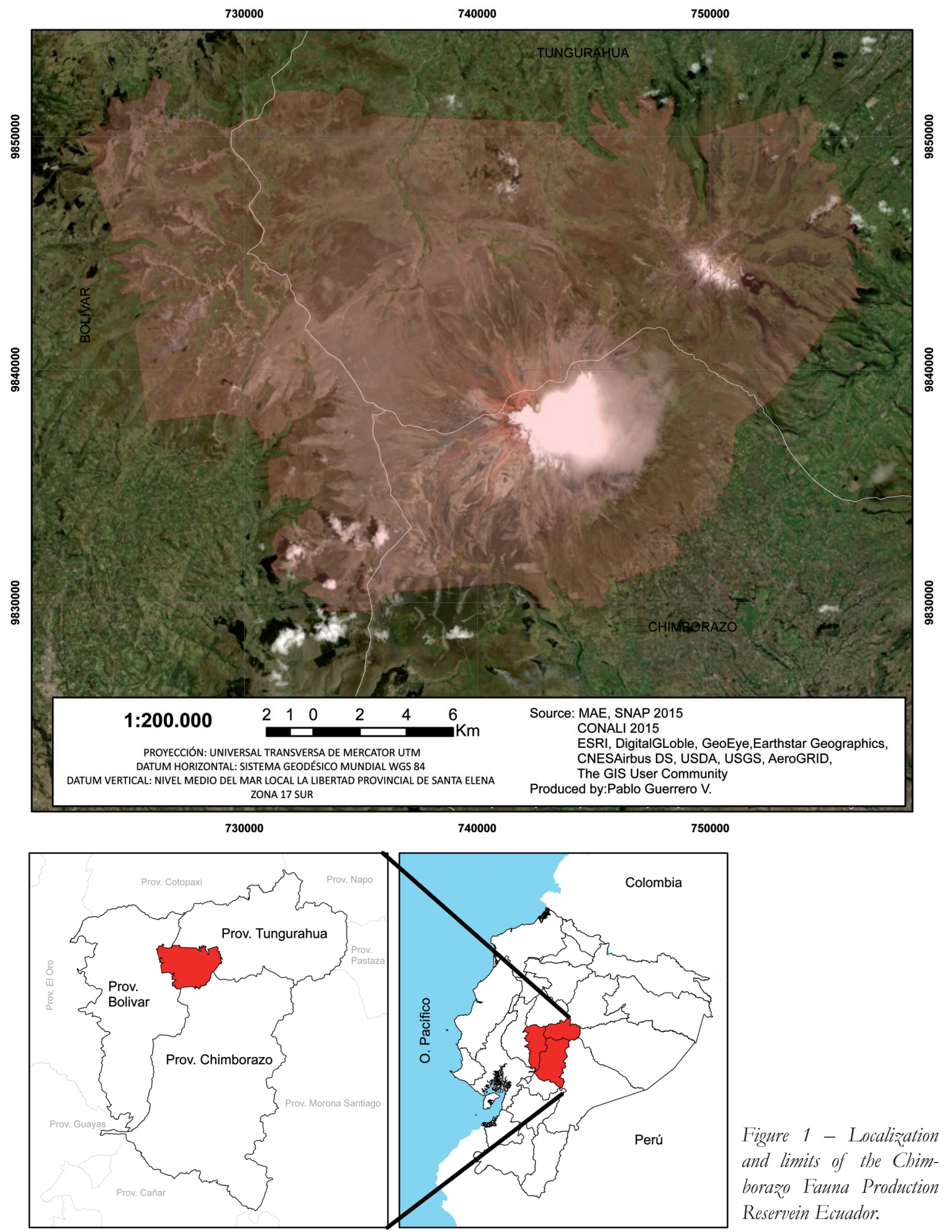

vival and reproduction. This Reserve was located in the empty zones lying within an area of 58560 hectares at altitudes of 3200 to $6310 \mathrm{~m}$.

We might say that PAs in Ecuador, including the $\mathrm{RPFCH}$, are areas that have recently been colonized by government institutions. They were located in socalled empty spaces which were first identified during the colonial era and then reinforced during the hacienda era, ${ }^{1}$ which ended in 1964 with the agrarian reform (Korovkin 1997). Meanwhile, the communities living in the mountains and páramos were excluded from

1 While agriculture in the early colonial period was predominantly characterized by the feudal encomienda system, the more (pre-)capitalist hacienda system started to develop at the end of the $18^{\text {th }}$ century in today's Ecuador and ended in the 1970's with the agrarian reform. 


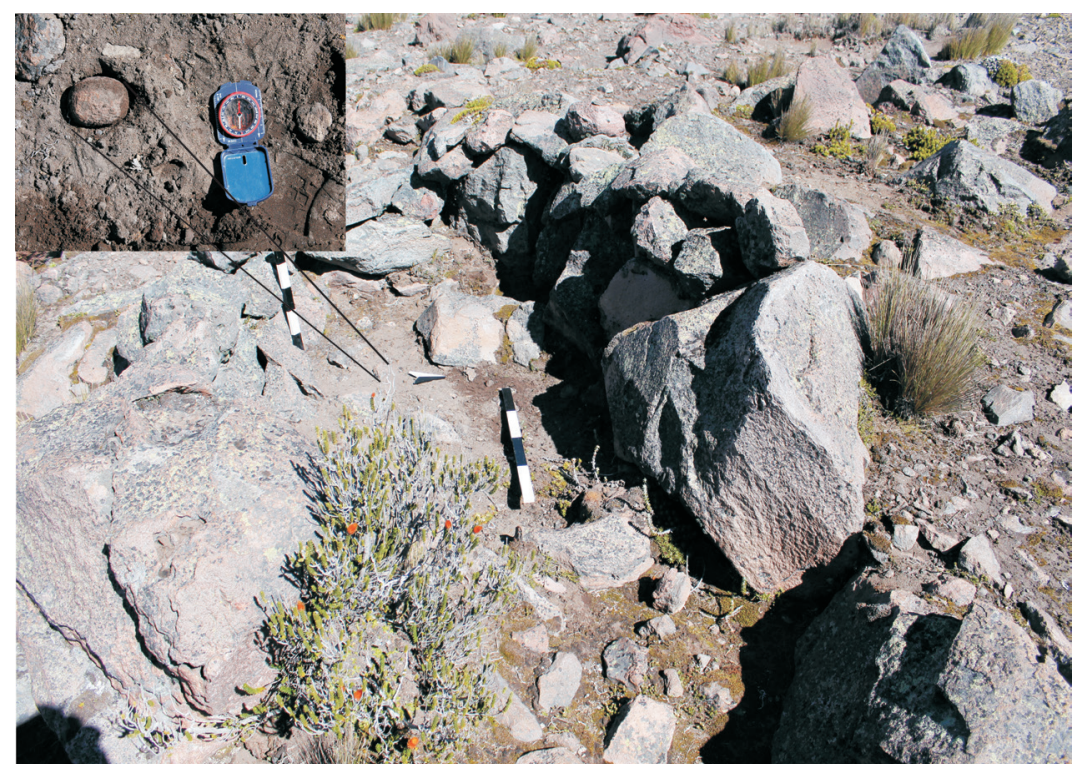

Figure 2 - A typical yata with a stone offering in the centre of the structure.

the PAs (Bustamante 2013), using the same reasoning - that is, that the regions near or above the páramos are empty spaces, or unimportant for human activities. Following the government's reasoning, these natural areas are to become useful spaces to preserve plant and animal species. The presence of people within them hinders Ecuador's state institutions in fixing the boundaries of the new territories.

\section{The creation of the Chimborazo Fauna Pro- duction Reserve and its purposes}

The RPFCH is located in the western cordillera of the Ecuadorian Andes in central Ecuador (Figure 1), in an area of young volcanoes. There are two large volcanoes in this PA: Chimborazo, best known for being the highest volcano in the world (6384 m) (Instituto Francés de Investigación para el Desarrollo 2016: 32-33), and Carihuairazo (5018 m), to the northeast of Chimborazo.

When scientific explorers arrived in what is now Ecuador, in the $19^{\text {th }}$ century, the two volcanoes were linked by both an extended glacier line at about 4700 $4800 \mathrm{~m}$ (Jomelli et al. 2009) and a snow line, giving the visual impression that they were a single mountain with two large peaks. Since the $19^{\text {th }}$ century, many studies have demonstrated the constant reduction in size of the glaciers on both mountains, as well as the increase in the number of gentians and the decrease of grasses or pajonal (Morueta-Holme et al. 2015: 12742). There are at least three main ecological zones distributed vertically. Their approximate annual average temperatures and altitudes are as follows (Sick 1963):

- Tierra Fría: $3000 \mathrm{~m}, 12^{\circ} \mathrm{C}$ in the valleys; $3500 \mathrm{~m}$, $8^{\circ} \mathrm{C}$ on the hillsides.

- Tierra Helada: $4000 \mathrm{~m}, 6^{\circ} \mathrm{C}$ (páramos); snow line at $4500 \mathrm{~m}$.

- Tierra Nival: $5000 \mathrm{~m}$.
It is important to note that the snow line is located at different altitudes on each side of Chimborazo volcano: it is at a lower altitude on the west side. The location of the vegetation depends on the distributional altitude of the permanent ice line (Borsdorf \& Stadel 1997: 137) and humidity.

This glaciological and botanical phenomenon is not unique to Chimborazo, but is present in other massive snow-capped volcanoes of the Andean cordilleras in Ecuador (e. g. Antisana). The altitudinal belts in the Ecuadorian Andes tend to accumulate greater humidity, and more snow and ice on their eastern flanks because of the wind-driven influence of the Amazonian weather, which also makes these eastern slopes verdant, while the western slopes are more parched (Sarmiento 2000: 426). Consequently, the superpáramo region (the area of vegetation bordering the snow line, above the páramo line) tends to be lower on the eastern side than on the western slopes (Sklenár \& Lægaard 2003: 8). The humidity gradients are different on the wind-and leeward sides of the volcano: there is a rain shadow on the western side, which results in a desertlike area on Chimborazo called the Arenal Grande, an area that has a unique, dry, páramo vegetation (Sklenár \& Lægaard 2003: 14).

In fact as Sklenár and Lægaard note citing AcostaSolís (1985), the western side of Chimborazo is similar to the dry and parched puna vegetation found in the central Andes of Bolivia and Peru (Sklenář \& Lægaard 2003: 14). Rather than this being an old situation resulting from a long adaptive process, it seems that the particular vegetation and geological landscape of Chimborazo's western slopes developed only recently (Sklenáŕ \& Lægaard 2003: 14). This led Ecuador's state institutions to include Chimborazo volcano in the new plan for the management and administration of the natural area and to create the RPFCH. 


\section{Camelid production and increasing con- flicts with communities}

The first group of 200 vicuñas, imported from Chile and Peru in 1985, were introduced to the area two years before the creation of the RPFCH. The second group were imported from Bolivia in 1988 (Baptista 2009: 16), one year after the RPFCH was established. In both cases, the animals belonged to the subspecies Vicugna vicugna mensalis. The idea was that they could bring economic benefits, because they appear to be a renewable resource: "They [the vicuñas] are not sacrificed after shearing their wool and they are released back into the parched paramos" (Rodríguez \& Morales 2017: 12). However, we know from Spanish chronicles that the principal and traditional animal in these areas was the llama, which was integrated into the religious beliefs of the Chimborazo people (Paz Maldonado 1992 [1582]; Moreno Yánez 2009; Aguiló 1978).

In my view, the introduction of Vicugna vicugna mensalis seems to follow a new, asynchronous perception of landscape by mestizo people from outside the immediate region who were inspired by experiences of breeding these animals in puna regions. The mestizos did not consult with local people, making no attempt to connect local expectations of exploiting the páramos in an area protected by the government to the wider discourse of global development or to NGOs' financial resources.

The introduction of this new subspecies took place in the territories of the RPFCH, with the supposed purpose of benefitting indigenous populations living around the volcano. However, in reality, the introduction was the product of a new discourse articulating the nascent interests of the government to justify its presence in traditional indigenous areas, within the context of a globalized worldview that emphasizes the need to maintain the sustainability of interactions between nature and humans. As Bustamante (2013: 2122) notes, PAs in Ecuador are to be seen in relation to an external discourse: Ecuadorian society tries to stage both nature for external agencies and its products, the Protected Areas. However, the creation and legitimation of a PA also generates the interests of another group of internal stakeholders, who benefit from the flow of financial resources.

Currently, there is mutual distrust between the state institutions (such as the RPFCH) and indigenous communities, because some of the touted benefits to the communities that were to be brought by the reintroduction of the vicuñas did not materialize (Baptista 2009: 96), and perhaps more importantly, because of the tension caused by the state's undemocratic decision to create the PA that includes the two volcanoes, Chimborazo and Carihuairazo - a decision that was not made in consultation with the indigenous communities. Instead, they were informed about it after the fact and were then excluded from their traditional lands.

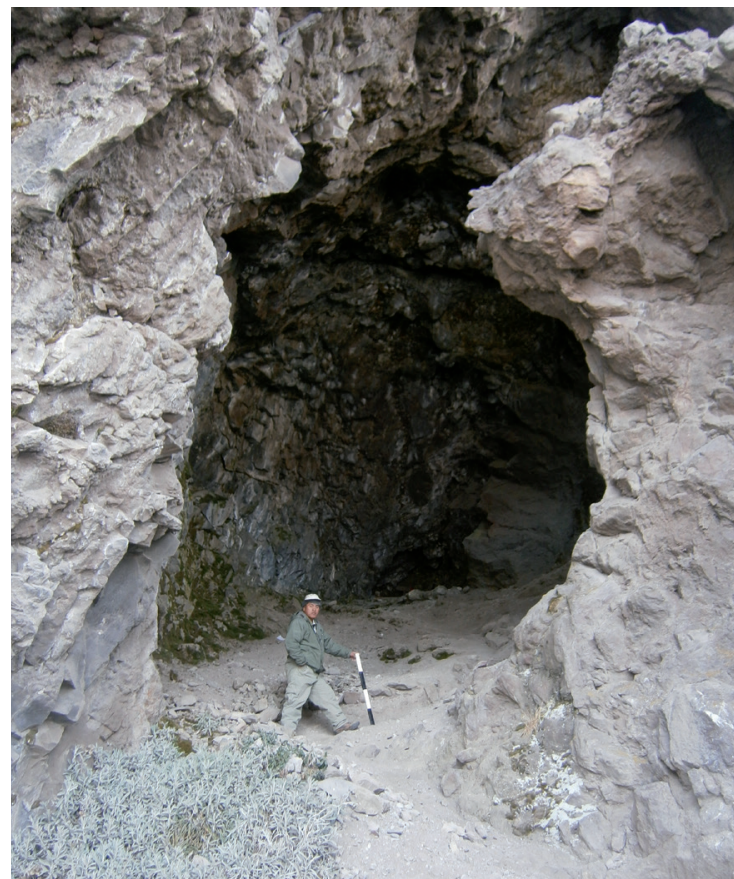

Figure 3 - Entrance to the cave known as Templo Machai.

\section{Early pre-hispanic occupation on Chimbo- razo volcano and its archaeological record}

At the foot of Chimborazo's glaciers on the western and southern slopes, local indigenous societies erected a series of buildings, from around $1350 \mathrm{AD}$ until the eighteenth century. These buildings were documented during a series of archaeological investigations carried out between 2012 and 2016, which included prospection and excavation phases (Yépez 2012, 2013, 2014, 2015, 2016). The buildings can be grouped into three archaeological complexes.

\section{Archaeological complex 1}

Complex 1 comprises approximately 70 small architectural structures dispersed over an area of around 2 ha. The area is located on the southwest side of Chimborazo, almost $700 \mathrm{~m}$ south of the Carrel Shelter (also known as the first shelter), in the Carrel valley (Jordan \& Buchrointhner 2009), at an altitude of 4780 to $4800 \mathrm{~m}$ a.s.l., a terrain with a gentle slope. These structures are known locally as yatas (Figure 2), which according to a local informant means "an openair place used to store food, which should be somehow covered or protected". This word can be found in the Aymara dictionaries dating from the seventeenth century (Bertonio 1984 [1612]; Torres Rubio [1616]), but not in the early Quichua dictionaries from the sixteenth century. Bertonio recorded a related word, yaatha, defining it as "to place some small rocks in lines to catch birds." He also recorded a derived word as "to close [a] plot of land or other things with rocks or with pieces of hard clay" (Bertonio 1984 [1612]: 389). I believe that this word is of Aymara origin, as opposed to Quichua, which might imply that 


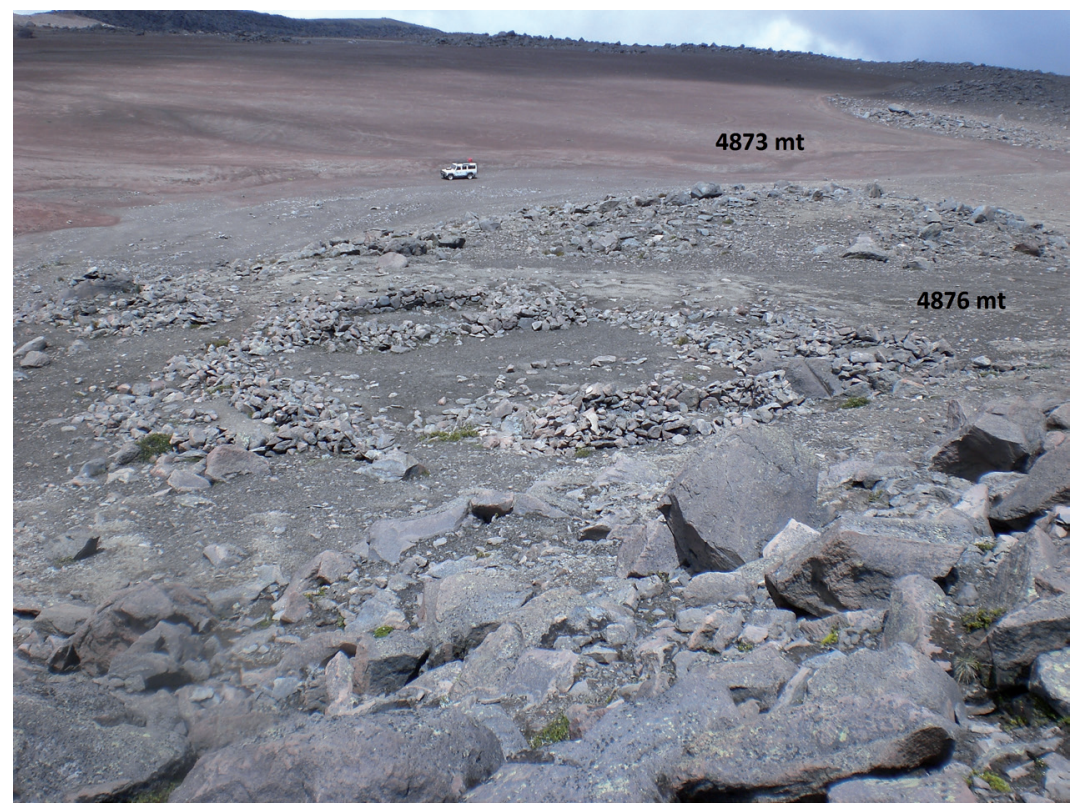

Figure 4 - Quadrangular structure known as a kancha, with Inca cultural filiation.

at some point during the prehispanic period, Aymaraspeaking populations arrived in the area.

\section{Archaeological complex 2}

On the west side of Chimborazo, between the Stübel and Thielmann glaciers, in the area known to mountain climbers as The Castle, along the route to the summit of Veintimilla, an enormous lava flow descends towards the southwest, between 5271 and $4873 \mathrm{~m}$ a.s.l. (Jordan \& Buchrointhner 2009). At the bottom end of the flow, there is a large, flat, semicircular area, of almost 11 ha, possibly the remains of a periglacial lake formed in the late Holocene. At about $5000 \mathrm{~m}$ a.s.l., the southern end of the magma flow hardened to create a semicircular promontory, formed by large semi-fractured rocks. At the base of this promontory, at $4876 \mathrm{~m}$ a.s.l., on a small flat area free of other rocks, we have identified an archaeological site consisting of four quadrangular structures and several artificial rock mounds. This flat area is oriented northeast to southeast; the southwest side slopes slightly. The cultural affiliation of the structures that form one building, known as a kancha, is Inca (Figure 3); the rock mounds are from colonial times, without any identified cultural affiliation.

\section{Archaeological complex 3}

On the south side of the volcano, using both information from the local oral tradition and GIS data, we found an ancient road that connects a tambo (a structure where travellers could rest), at about $3700 \mathrm{~m}$ a.s.l., which is most likely of Inca origin given its kancha shape, with a set of at least 14 other archaeological sites (yaathas). These are located near a cave of volcanic origin, known locally as the Templo Machai (Figure 4). Both features (the sites and the cave) are at approximately $4670 \mathrm{~m}$ a.s.l., and 150 linear $\mathrm{m}$ apart. The cave is the destination of present-day religious pilgrimages, and we believe that the nearby archaeological sites were used for religious purposes in prehispanic times. After studying the road that connects the tambo with the archaeological sites nearby, we concluded that the cave served as a special, symbolic marker for the pilgrims and priests who travelled to the yaathas on this side of the volcano.

In this study to evaluate the archaeological sites on Chimborazo volcano, we aim to innovate the traditional administrative structure of RPFCH by the addition of criteria for faunal protection. Our objective is to move away from the current scenario of the selective use of archaeological evidence and to stop the perpetuation of mistaken ideas about the past. We think that an appropriate, and pioneering, implementation of the cultural landscape concept in the Chimborazo volcano area could motivate the Ecuadorian administrative bodies responsible for protected natural areas in the Ecuadorian highlands to innovate their traditional administration systems focused on nature.

\section{Heritage valuation of high-altitude sacred sites on Chimborazo volcano}

In both Europe and Latin America, mountains and their cultural and natural landscapes are part of the common ancestral heritage, resulting from the age-old interaction between humans and the environment. It is interesting to note, however, that in PAs in the European Alps (Austria, Slovenia, Germany, Italy, Switzerland and France) the sacred dimension is not integrated as one of the research themes that characterize the conceptual management of a PA (Braun 2010), although the historical component in some natural parks is indeed considered (Braun 2010: Table 1, 59).

In recent years, there has been some move in Europe to integrate religious and sacred components into the conceptualization of a landscape as a new criterion 
for the protection and management of a natural area (Cooney 2013; Marciniak 2013; Hubert 2013). This is an incipient trend in Europe. On the other hand, in Latin America this is already a strong tendency that the UNESCO and IUCN ought to recognize as a leading criterion to protect natural areas (Verschnuuren et al. 2017: 16-17). In this context, and as Viteri (2017) states, it is important to point out that Ecuador is a signatory of the United Nations Heritage Convention, that Sacred Sites are a new, important, recognized element of cultural landscapes, and that their vernacular and natural values should be integrated in the management and conservation of PAs (Viteri 2017: 209). In addition, the delimitation and definition of a PA should go beyond the dichotomy between territories for nature protection and spaces for human activities, as Vilsmaier remarks, and evolve into an active approach that aims for societal transformation for sustainable development (Vilsmaier 2010: 37).

The current status of RPFCH in the Chimborazo region, as level IV in the IUCN's scheme, must evolve into a new conceptual order that integrates the archaeological, cultural, religious and sacred dimensions of the natural area through a new, negotiated, consensus between stakeholders, government institutions and the academic community. The cultural landscape concept, recently discussed in Quito and recognized in law by the Ecuadorian Ministry of Culture and Heritage in December 2016 (Viteri, 2017: 210), could be appropriate for informing this new order. It is a category that has been adopted by UNESCO (recognized in customary law) and that figures in management systems globally (Bandarin 2009).

This new effort to recognize the RPFCH as a cultural landscape area seeks to move the interested parties in two directions: an interdisciplinary direction and a transdisciplinary one. Any research that takes place should maintain the dialogue and information exchange between different scientific disciplines (the interdisciplinary sphere). It is also imperative to achieve not only consensus agreements among the different parties, in order to ensure the sustainability of the area, but also to put in place a permanent control system to ensure the ongoing evaluation of those agreements (the transdisciplinary sphere).

\section{References}

Acosta-Solís, M. 1985. El Arenal del Chimborazo, ejemplo de puna en el Ecuador. Revista Geográfica 22: 115-122. [In Spanish]

Aguiló, F. 1978. El hombre del Chimborazo y su mundo interior. Cuenca. [In Spanish]

Bandarin, F. 2009. Preface. In: Mitchell, N., M. Rössler \& P.-M. Tricaud (eds.), World Heritage Cultural Landscapes. A Handbook for Conservation and Management: 3-4. Available at: https://whc.unesco. org/documents/publi_wh_papers_26_en.pdf
Baptista, V. 2009. Los camélidos en la reserva de producción de fauna chimborazo: ¿una alternativa para la sustentabilidad del páramo? Estudio de caso en torno a la organización campesina, la economía y la gobernanza ambiental. Tesis de Maestría. Facultad Latinoamericana de Ciencias Sociales. Quito. [In Spanish]

Barba, D. 2006. Estudio Vulcanólogico del Complejo Volcánico Chimborazo. Tesis de ingeniería geológica. Escuela Politécnica Nacional del Ecuador. Quito. Available at: http://bibdigital.epn.edu.ec/handle/15000/144 [In Spanish]

Bertonio, L. 1984 [1612]. Vocabulario de la lengua Aymara. Cochabamba. [In Spanish]

Borsdorf, A. \& C. Stadel 1997. Ecuador in Profilen. inngeo 3 - Innsbrucker Materialien zur Geographie 3. Innsbruck. Available at: http://www.uibk.ac.at/ geographie/shop/inngeo/band3.html [In German]

Braun, V. 2010. Research concepts in protected areas in the Alps. eco.mont - Journal on protected mountain areas research and management 2(2): 55-60.

Bustamante, T. 2013. Una interpretación de la naturaleza y el espacio en el Ecuador. Las áreas protegidas como discurso actual de conservación. Tesis doctoral. Universidad de Salamanca. [In Spanish]

Ceruti, M.C. 2017. Frozen mummies and the archaeology of high mountains in the construction of Andean identity. In: Sarmiento, F. \& S. Hitchner (eds.), Indigeneity and the sacred. Indigenous revival and the conservation of sacred natural sites in the Americas: 105-118. Oxford.

Cooney, C. 2013. Sacred and secular neolithic landscapes in Ireland. In: Carmichael, D.L, J. Hubert, B. Reeves \& A. Schanche (eds.), Sacred sites, sacred places: 32-43.

Hubert, J. 2013. Sacred beliefs and beliefs of sacredness. In: Carmichael, D.L., J. Hubert, B. Reeves \& A. Schanche (eds.), Sacred sites, sacred places: 9-19.

Instituto Francés de Investigación para el Desarrollo (IRD) 2016. Chimborazo. Misión al cenit. Nan 22: 28-35. Quito. [In Spanish]

Jomelli, V., V. Favier, A. Rabatel, D. Brunstein, G. Hoffmann \& B. Francou 2009. Fluctuations of glaciers in the tropical Andes over the last millennium and palaeoclimatic implications: A review. Palaeogeography, Palaeoclimatology, Palaeoecology 281: 269-282.

Jordan, E. \& M. Buchrointhner 2009. Nevado Chimborazo, Ecuador. Trekking / Orthophotokarte. 1:2000. Düsseldorf / Dresden.

Korovkin, T. 1997. Indigenous Peasant Struggles and the Capitalist Modernization of Agriculture: Chimborazo, 1964-1991. Latin American Perspectives 24 (3, 94): 25-29. Thousand Oaks.

Lauer, W. 1975. Vom Wesen der Tropen. Klimaökologische Studien zum Inhalt und zur Abgrenzung eines irdischen Landschafisgürtels. Wiesbaden. [In German]

Marciniak, K. 2013. The perception and treatment of prehistoric and contemporary sacred places and Sites in Poland. In: Carmichael, D.L., J. Hubert, B. 
Reeves \& A. Schanche (eds.), Sacred sites, sacred places: 140-151.

Moreno Yánez, S. 2009. El Chimborazo, Ecuador: un ancestro sagrado andino. In: Topic, J. (ed.), La arqueología y la etnohistoria: un encuentro andino: 25-52. Lima. [In Spanish]

Morueta-Holme, N., K. Engemann, P. SandovalAcuña, J.D. Jonas, R. Max, Segnitz \& J.-C. Svenning 2015. Strong upslope shifts in Chimborazo's vegetation over two centuries since Humboldt. Proceedings of the National Academy of Sciences of the United States of America 112(41): 12741-12745.

Oberem, U. 1978. Archipel-System und/oder Handel? Ein Beitrag zur wirtschaftlichen Organisation der Indianer Ecuadors im 16. Jahrhundert. In: Schneider, J. (ed.), Wirtschaftskräfte und Wirtschaftswege - Festschrift für Hermann Kellenben₹, IV: Übersee und allgemeine Wirtschaftsgeschichte: 187-199. Stuttgart, Nürnberg. [In German]

Oberem, U. 1981. El acceso a recursos naturales de diferentes ecologías en la Sierra ecuatoriana (siglo XVI). In: Moreno Yánez, S. (ed.), Contribución a la etnohistoria ecuatoriana. Serie etnohistoria. Pendoneros 20: 45-72, Otavalo. [In Spanish]

Paz Maldonado, J. (1992 [1582]). Relación del Pueblo de San Andrés de Xunxi, provincia de Riobamba. In: Ponce Leiva, P. (ed.), Relaciones histórico-geográficas de la Audiencia de Quito (siglo XVI-XIX): 319-331. Quito. [In Spanish]

Rodríguez, N. \& A. Morales 2017. La vicuña ecuatoriana y su entorno/Ecuador mamallaktapi tiyak wikuña paypak kuskapi. Available at: http:// maetransparente.ambiente.gob.ec/documentacion/ B i o diversidad / L A _ V I C U \% C 3\%91 A_ ECUATORIANA.pdf [In Spanish]

Sarmiento, F. 2000. Breaking mountain paradigms: ecological effects on human impacts in managed tropandean landscapes. Ambio 29(7): 423-431.

Sick, W.D. 1963. Wirtschaftsgeographie von Ecuador. Stuttgarter Geographische Studien 73: 1-275. [In German]

Sklenár, P. \& S. Lægaard 2003. Rain-shadow in the high Andes of Ecuador evidenced by Páramo vegetation. Arctic, Antarctic, and Alpine Research 35(1): 8-17.

Stadel, C. 1990. Altitudinal belts in the tropical Andes: their ecology and human utilization. Conference of
Latin Americanist Geographers 17/18: 45-60. Available at: https://www.jstor.org/stable/25765738

Stahl, P. 2003. Pre-Columbian Andean animal domesticates at the edge of empire. World Archaeology 34 (3): 470-483.

Torres Rubio, D. 1616. El arte de la lengua aimara. Available at: https://archive.org/stream/ artedelalenguaay00torr\#page/n209/mode/2up [In Spanish]

Verschnuuren, B., R. Wild \& G. Verschoor 2017. Connecting policy and practice for the conservation of sacred natural places. In: Sarmiento, F. \& S. Hitchner, Indigeneity and the sacred: 11-40. New York.

Vilsmaier, U. 2010. Transdisciplinarity and protected areas: A matter of research horizon. eco.mont Journal on protected mountain areas research and management 2(2): 37-43.

Viteri, J. 2017. New dimensions in the territorial conservation management in Ecuador: a brief political view of sacred sites in Ecuador. In: Sarmiento, F. \& S. Hitchner, Indigeneity and the sacred: 205-213. New York.

Yépez, A. 2012. Prospección arqueológica de altura en el flanco oeste del volcán Chimborazo. Informe de investigación arqueológica presentado a INPC-Quito. [In Spanish]

Yépez, A. 2013. Excavaciones en dos recintos arqueológicos de altura. Informe de investigación arqueológica presentado a INPC-Quito. [In Spanish]

Yépez, A. 2014. Prospección arqueológica en el flanco sur del volcán Chimborazo. Informe de investigación arqueológica presentado a INPC-Quito. [In Spanish]

Yépez, A. 2015-2016. Patrones de ingesta de altura en el volcán Chimborazo. Informe de investigación arqueológica presentado a INPC-Quito. [In Spanish]

\section{Author}

\section{Alden Mauro Yepez Noboa}

Degree in Ethnology from the Catholic University of Quito, Ecuador (2000). Doctorate at the University of Bonn (2008). 2007-2010 Lecturer at the University of Bonn. 2012 to present Lecturer at the Catholic University in Quito, Ecuador. 